\section{Influence of Resin Cements on Color Stability of Different Ceramic Systems}

Renata Borges Rodrigues' ${ }^{1}$ Erick de Lima², Marina Guimarães Roscoe ${ }^{3}$, Carlos

José Soares ${ }^{1}$, Paulo Francisco Cesar ${ }^{2}$, Veridiana Resende Novais ${ }^{1}$

The purpose of this study was to evaluate color stability of two dental ceramics cemented with two resin cements, assessing the color difference $\left(\Delta \mathrm{E}_{00}\right)$ by the measurement of $\mathrm{L}^{*}, \mathrm{a}^{*}$, $\mathrm{b}^{*}, \mathrm{c}^{*}$ and $\mathrm{h}^{*}$ of transmittance. The combination of two ceramic system (feldspathic and lithium disilicate) and two resin cements - color A3 (RelyX ARC and Variolink II) resulted in 4 groups $(n=5)$. Ten disks-shaped specimens were fabricated for each ceramic system $(10 \times 1.5 \mathrm{~mm})$, etched with hydrofluoric acid $(10 \%)$ and silanized prior to cementation. The color analysis was performed $24 \mathrm{~h}$ after cementation of the samples and after 6 months of storage in relative humidity by means of spectrophotometry. The $\Delta \mathrm{E}_{00}$ values were analyzed statistically by two-way ANOVA followed by the Tukey test $(p<0.05)$. One-way ANOVA were calculated for the means of individual color coordinates $\left(L^{*}, a^{*}, b^{*}, c^{*}\right.$ and $\left.h^{*}\right)$. Two-way ANOVA showed that only the ceramic factor was significant $(p=0.003)$, but there was no difference for the cement factor $(p=0.275)$ nor for the ceramic/cement interaction $(p=0.161)$. The feldspathic ceramic showed the highest values of $\Delta E_{00}$. Variations in $L^{*}, a^{*}$, $b^{*}, c^{*}$ and $h^{*}$ were more significant for feldspathic ceramic. In conclusion, storage alters similarly the optical properties of the resin cements and feldspathic porcelain was more susceptible to cement color change after aging.
'Department of Operative Dentistry and Dental Materials, Dental School, UFU - Universidade Federal de Uberlândia, Uberlândia, MG, Brazil ${ }^{2}$ Department of Biomaterials and Oral Biology, Dental School, USP - Universidade de São Paulo, São Paulo, SP, Brazil ${ }^{3}$ Department of Orthodontics, Dental School, UNG - Universidade Guarulhos, Guarulhos, SP, Brazil

Correspondence: Profa. Dra. Veridiana Resende Novais, Av Pará 1720, Bloco 4L, Anexo A, $3^{\circ}$ Andar, sala A32 Campus Umuarama, 38400-902 Uberlândia, MG, Brasil. Tel: +55-34-3225-8105. e-mail: veridianaresende@hotmail.com

Key Worlds: dual-polymerizing cement, feldspathic ceramic, lithium-disilicate pressed glass, optical properties, storage.

\section{Introduction}

All-ceramic restorations provide excellent esthetic outcomes and have advantages compared with metalceramic systems, such as color stability and excellent ability to mimic the tooth structure (1). However, a major challenge to aesthetic restorations is to provide optical behavior similar to natural teeth (2). The optical properties of a ceramic system depend on their translucency, opalescence, fluorescence, surface texture and shape, firing temperature, number of firing cycles, thickness, processing method and the used resin cement (3-5).

In the dental practice, choice of the ceramic system should be based on the mechanical and optical properties of the material $(6,7)$. The first available all-ceramic crowns were produced with feldspathic ceramics (8) and until today this material is widely used due to its excellent optical properties (9). However, its brittleness and low flexural strength led to the development of other ceramic materials $(6,7)$, like lithium disilicate ceramic, a semi translucent glass-ceramic with a microstructure containing around $60 \%$ acicular lithium disilicate crystals surrounded by a glassy matrix. Due to its strength, optical properties and abrasion behavior, lithium disilicate restorations proved to have a relatively high clinical long-term success $(7,10)$.

The final color of all-ceramic restorations depends on three main factors and their interaction: color of the tooth/substructure; thickness of ceramic and resin cement, and ceramic system and resin cement type $(11,12)$. Resin cements may mask the underlying color and modify the final color of the restoration; therefore, controlling and balancing its opacity and color parameters is key to achieve good final aesthetic outcomes (13).

An important concern regarding the cementation step is to ensure optimal polymerization of the resin cement, since this influences its long-term color stability (10). Discoloration of the cement layer may adversely affect the final color of all-ceramic restorations with time (10). Cement discoloration is usually associated with degradation of the unreacted polymer matrix during the polymerization and to extrinsic factors $(14,15)$. Dual-polymerizing resin cements have lower color stability due to oxidation of the polymerization initiators, like tertiary amines that did not react during polymerization. The presence of unreacted benzoyl peroxide can also lead to color instability, jeopardizing the long-term aesthetics of the restoration $(10,15,16)$.

The aim of this study was to evaluate the effect of storage time on the color stability of two ceramic systems (feldspathic ceramic or lithium disilicate) cemented with different resin cements. The null hypothesis was that the color stability of different ceramic systems and resin cements would not be influenced by the storage time.

\section{Material and Methods Preparation of Ceramic Discs}

Two ceramic systems - Feldspathic (Super Porcelain EX-3, Kuraray Noritake Dental Inc, Miyoshi Japan) and 
Lithium-disilicate pressed glass ceramic (Ivoclar-Vivadent, Schaan, Liechtenstein) - cemented with two A3 shade resin cements - Rely X ARC (3M ESPE, St. Paul, MN, USA) and Variolink II (Ivoclar-Vivadent) - were evaluated (Table 1). Ten disk-shaped ceramic specimens $(1.5 \mathrm{~mm}$ thick and $10 \mathrm{~mm}$ diameter) were fabricated for each ceramic system and had their dimensions confirmed with a digital calliper (Mitutoyo Corp., Tokyo, Japan). Silicon carbide paper \#320, \#600, \#1200 and \#2000 was used to provide surface standardization. Glaze application and firing cycle were performed as recommended by the manufacturer. The specimens were ultrasonically cleaned using distilled water for $10 \mathrm{~min}$. The disk-shaped ceramics were divided in four groups $(n=5)$.

\section{Cementation of Ceramic Discs}

Ceramic discs surface conditioning was performed before cementation: 1- feldspathic ceramic - application of 10\% hydrofluoric acid (Condac, FGM, Joinville, SC, Brazil) for $2 \mathrm{~min}$, rinsed with air/water spray for $1 \mathrm{~min}$, air-dried for $1 \mathrm{~min}$, followed by ultrasound cleaning for $5 \mathrm{~min}$ in distilled water. Next, a silane coupling agent was applied (Prosil, FGM, Joinville, SC, Brazil) for 1 min, followed by $\Xi$ air jet; 2- lithium-disilicate pressed glass ceramic - 10\% hydrofluoric acid (Condac, FGM) application for $20 \mathrm{~s}$, rinsed with air/water spray for $1 \mathrm{~min}$, air-dried for 1 min, ultrasound cleaning for 5 min in distilled water and coupling agent (silane) application (Prosil, FGM) for 1 min, followed by air jet.

A Teflon ${ }^{\circledR}$ matrix (1.8 $\mathrm{mm}$ high and $10 \mathrm{~mm}$ diameter) was used for the luting process. Thus, the cement thickness was standardized at $0.3 \mathrm{~mm}$, as the ceramic disk had a 1.5 $\mathrm{mm}$ thickness. The matrix was placed on a polyester strip (Airon, Maringa, PR, Brazil). Each cement was manipulated for $10 \mathrm{~s}$ and then placed into the matrix. The ceramic disk was immediately, placed on the cement and was positioned over the cement layer inside the matrix. The excess was removed with a microbrush (FGM, Joinville, SC, Brazil) and

Table 1. Materials evaluated in this study

\begin{tabular}{lccc}
\hline Type of Material & Product & Color & Manufacturer \\
\hline $\begin{array}{l}\text { Feldspathic } \\
\text { ceramic }\end{array}$ & Noritake & Dentine A ${ }_{3}$ B & $\begin{array}{c}\text { Kuraray, Miyoshi } \\
\text { Japan }\end{array}$ \\
$\begin{array}{l}\text { Ceramic reinforced } \\
\text { with lithium } \\
\text { disilicate }\end{array}$ & $\begin{array}{c}\text { IPS E-max } \\
\text { Press }\end{array}$ & Dentine A3 & $\begin{array}{c}\text { Ivoclar-Vivadent, } \\
\text { Schaan, } \\
\text { Liechtenstein }\end{array}$ \\
$\begin{array}{l}\text { Dual-polymerizing } \\
\text { resin cement }\end{array}$ & Variolink II & A3 & $\begin{array}{c}\text { Ivoclar-Vivadent } \\
\text { Schaan, } \\
\text { Dual-polymerizing } \\
\text { resin cement }\end{array}$ \\
\hline
\end{tabular}

then left for a for 5 min chemical polymerization (17). The specimens were light polymerized using halogen light through the ceramic with $800 \mathrm{~mW} / \mathrm{cm}^{2}$ intensity (Optilux 501; Demetron, Danbury, CT, USA) for 120 s. After curing, the specimens were stored in a dark container at room temperature, with relative humidity, for $24 \mathrm{~h}$ for color analysis.

\section{Measurement of Color Difference}

Color difference was measured using a spectrophotometer (CM-37000d; Konica Minolta, Tokyo, Japan) with wavelength $(\lambda)$ ranging from $360 \mathrm{~nm}$ to $740 \mathrm{~nm}$ with $10 \mathrm{~nm}$ interval. The $L^{*}, a^{*}, b^{*}, c^{*}$ and $h^{*}$ parameters were measured according to the Commission Internationale de l'Éclairage (CIE), in which $L^{*}$ is the lightness, $a^{*}$ corresponds to the red-green axis value and $b^{*}$ to the yellow-blue axis value in the CIELAB color-space (CIE 1976), $c^{*}$ represents chrome and $h^{*}$ the hue (18). The parameters for calculating the color difference were standardized with illuminant D65 and observer function at $2^{\circ}$. The analysis of the optical properties was performed by measuring the light transmittance (with no background) in two different time points: $24 \mathrm{~h}$ after preparation of the samples and six months after storage in a dark environment with controlled temperature $\left(37^{\circ} \mathrm{C}\right)$ in relative humidity.

The color difference was calculated using the CIEDE2000 $\left(\Delta \mathrm{E}_{00}\right)$ formula (19):

$$
\Delta \mathrm{E}^{\prime}=\left[\left(\frac{\Delta \mathrm{L}^{\prime}}{K_{L} S_{L}}\right)^{2}+\left(\frac{\Delta \mathrm{C}^{\prime}}{K_{C} S_{C}}\right)^{2}+\left(\frac{\Delta \mathrm{H}^{\prime}}{K_{H} S_{H}}\right)^{2}+R_{T}\left(\frac{\Delta \mathrm{C}^{\prime}}{K_{C} S_{C}}\right)\left(\frac{\Delta \mathrm{H}^{\prime}}{K_{H} S_{H}}\right)\right]^{1 / 2}
$$

Where $\Delta \mathrm{L}^{\prime}, \Delta \mathrm{C}^{\prime}$, and $\Delta \mathrm{H}^{\prime}$ are the differences in lightness, chroma, and hue for a pair of samples (before and after aging) in CIEDE2000, and $R_{T}$ is a function (the so-called rotation function) that accounts for the interaction between chroma and hue differences in the blue region (19). Weighting functions, $S_{L}, S_{C}, S_{H}$ adjust the total color difference for variation in the location of the color difference pair in $L, a, b$ coordinates and the parametric factors; $\mathrm{K}_{\mathrm{L}}, \mathrm{K}_{\mathrm{C}} \mathrm{K}_{\mathrm{H}}$ are correction terms for experimental conditions. In the present study, the parametric factors of the CIEDE2000 color difference formula were set at 1 (19).

\section{Statistical Analysis}

The data were tested for normal distribution (Shapiro-Wilk, $p>0.05$ ) and equality of variances (Levene's test, $p>0.05$ ), followed by parametric statistical tests. Two-way ANOVA was used on the values of $\left(\Delta \mathrm{E}_{00}\right)$ for transmittance. One-way ANOVA was performed on individual variations of $L^{*}, a^{*}, b^{*}$, $c^{*}$ and $h^{*}$ for each group. All tests employed $\alpha=0.05$ 
level of statistical significance and were carried out with the statistical package Sigma Plot version 12.0 (Systat Software, Inc., San Jose, CA, USA).

\section{Results}

Means and standard deviations of the color variation before and after aging $\left(\Delta \mathrm{E}_{00}\right)$ are in Table 2. Two-way ANOVA showed that in terms of color stability, only the ceramic factor was statistically significant $(p=0.003)$. The factor cement $(p=0.275)$, and the ceramic/cement interaction $(p=0.161)$ were not statistically significant. Table 2 shows that, regardless the considered resin cement, feldspathic ceramic always resulted in significantly higher $\Delta \mathrm{E}_{00}$ value compared to the lithium-disilicate pressed glass ceramic. In fact, feldspathic $\Delta \mathrm{E}_{00}$ value was more than double that of lithium-disilicate pressed glass ceramic when Variolink II was used.

Variations in individual color coordinates between the control and aged specimens are in Table 3. There were significant changes after aging for all coordinates in feldspathic groups for both cements. In lithium-disilicate pressed glass ceramic group, for both cements there were statistical differences only for the $\mathrm{a}^{*}$ and $\mathrm{h}^{*}$ coordinates.

Table 2. Mean and standard deviation of $\Delta \mathrm{E}_{00}$ (initial color variation and after six months) for transmittance

\begin{tabular}{llc}
\hline \multirow{2}{*}{ Ceramic } & \multicolumn{2}{c}{ Resin Cements } \\
\cline { 2 - 3 } & Rely X ARC & Variolink II \\
\hline Emax & $3.85(0.53) \mathrm{Ba}$ & $3.64(0.31) \mathrm{Ba}$ \\
Feldspathic & $5.82(3.58) \mathrm{Aa}$ & $8.15(3.32) \mathrm{Aa}$ \\
\hline
\end{tabular}

Means followed by different uppercase letters within columns and lowercase letters within rows are significantly different (statistical categories defined by Tukey test; $\mathrm{p}<0.05$ ).

\section{Discussion}

The tested null hypothesis was rejected because the type of ceramic affected significantly the specimen's color stability.

This study evaluated the translucency of dental porcelains, by direct transmitance measurement (20). In this analysis, the sample is positioned without any background material, so that only the studied factors (ceramic and cement) would influence the amount of light transmitted by the sample. The parameters used were those of a color system (color space) created by the International Commission of Illumination (Commission Internationale de l'Eclairage) (18). In this system, the $L^{*}$ parameter represents the brightness (lightness), $a^{*}$ is the red-green chromatic coordinate (positive $\mathrm{a}^{*}$ indicates red and negative $a^{*}$ indicates green) and $b^{*}$ is the yellow-blue chromatic coordinate (positive $b^{*}$ indicates yellow and negative $b^{*}$ indicates blue), $c^{*}$ represents chrome and $h^{*}$ the hue (18). The color difference after aging was calculated by CIE2000 $\left(\Delta \mathrm{E}_{00}\right)$, a formula recommended for studies of optical properties of dental ceramics (19). The $\Delta \mathrm{E}_{00}$ values of all groups were higher than 2.25 , which is the $50 \%$ acceptability threshold values for color alteration of dental materials (19).

A high $\Delta \mathrm{E}$ value indicates a high variation in color properties as function of storage time. The results of this study showed that feldspathic ceramic showed a significant difference in color when compared to lithium-disilicate pressed glass ceramic, regardless the resin cement. This may be seen by the $\Delta \mathrm{E}_{00}$ values shown in Table 2. For feldspathic ceramic, all color coordinates changed after aging, regardless the considered resin cement (Table 3).

The lack of significance for cement factor indicates that both used cements had the same degradation behavior in a humid environment despite the composition

Table 3. Mean and standard deviations of individual color coordinates for all groups

\begin{tabular}{lcccccc}
\hline \multirow{2}{*}{ Group } & Color reading & \multicolumn{5}{c}{ Color coordinates } \\
\cline { 3 - 7 } & Initial & $51.04(3.54) \mathrm{b}$ & $0.17(0.2) \mathrm{b}$ & $19.25(1.93) \mathrm{b}$ & $19.26(1.93) \mathrm{b}$ & $87.8(0.39) \mathrm{a}$ \\
\hline \multirow{2}{*}{ Feldspathic ARC } & 6 months & $55.67(0.88) \mathrm{a}$ & $2.63(0.16) \mathrm{a}$ & $21.91(0.71) \mathrm{a}$ & $22.07(0.72) \mathrm{a}$ & $83.15(0.21) \mathrm{b}$ \\
& Initial & $50.29(3.17) \mathrm{b}$ & $0.64(0.18) \mathrm{b}$ & $18.61(1.47) \mathrm{b}$ & $18.62(1.47) \mathrm{b}$ & $88.03(0.43) \mathrm{a}$ \\
& 6 months & $56.37(4.1) \mathrm{a}$ & $2.36(0.26) \mathrm{a}$ & $20.69(1.01) \mathrm{a}$ & $20.82(1.01) \mathrm{a}$ & $83.49(0.69) \mathrm{b}$ \\
Feldspathic Variolink II & Initial & $56.9(2.98) \mathrm{a}$ & $1.26(0.29) \mathrm{b}$ & $21.74(1.96) \mathrm{a}$ & $21.78(1.97) \mathrm{a}$ & $86.72(0.48) \mathrm{a}$ \\
& 6 months & $56.73(3.43) \mathrm{a}$ & $3.04(0.51) \mathrm{a}$ & $22.35(2.31) \mathrm{a}$ & $22.55(2.36) \mathrm{a}$ & $82.29(0.5) \mathrm{b}$ \\
Emax ARC & Initial & $57.88(2.4) \mathrm{a}$ & $1.2(0.2) \mathrm{b}$ & $20.91(1.21) \mathrm{a}$ & $20.94(1.22) \mathrm{a}$ & $86.72(0.43) \mathrm{a}$ \\
& 6 months & $58.02(1.44) \mathrm{a}$ & $2.78(0.27) \mathrm{a}$ & $21.08(1.69) \mathrm{a}$ & $21.26(1.71) \mathrm{a}$ & $82.47(0.19) \mathrm{b}$ \\
\hline
\end{tabular}

For each group, different letters indicate significant differences $(\mathrm{p}<0.05)$ between initial and 6 month measurements for each color coordinate. 
differences between them. Dual-polymerizing activated resin systems have some advantages compared to photoactivated cements in terms of working time and polymerization shrinkage. Besides that, they also show superior mechanical properties, like flexural strength, elastic modulus, hardness and degree of conversion in comparison to those materials that are only light activated (21). However, dual polymerizing cements have tertiary amines in their composition that act as chemical initiators for the polymerization reaction. For this reaction to occur, oxidation of the amine reactive groups is necessary and this may cause color changes $(16,22)$. These materials contain a combination of different amines. One amine reacts with benzoyl peroxide (chemical polymerization) that is generally aromatic and more prone to degradation and another amine reacts with camphorquinone (light polymerizing) $(15,16,23)$. The latter is usually aliphatic and chemically more stable. In the chemical reaction, the unreacted benzoyl peroxide may also cause color instability $(15,16,23)$. The chemical reaction between the amine and benzoyl peroxide is not very efficient, because it depends on the physical linkage of both molecules during the polymerization reaction (14). In the present study, the standardization of the thickness cement layer and the chemical polymerization time ( $5 \mathrm{~min}$ ) (17) for both cements, may have influenced the optical properties, considering that this time ensured an effective chemical polymerization and therefore, no effect of the cement on the color change was noticed.

The difference in optical behavior between both evaluated ceramic systems, feldspathic and lithiumdisilicate pressed glass ceramic, is related to their microstructure $(5,24)$. The interaction of light with the ceramic material depends on the amount (fraction), size and crystal composition and glassy matrix (9). Furthermore, the light beam scatters when there is a difference in refractive index between two phases, so that the higher the refractive index and the number of phases, the higher the scattering effect, resulting in a more opaque material (25). Lithium-disilicate pressed glass ceramic has a greater crystal fraction compared to feldspathic ceramic. When light beam hits this material, it will pass through a series of intercepts (interface between two phases) resulting in greater light scattering and hence a greater opacity (25). In the feldspathic porcelain, the light beam travels longer distances in the same phase and crossing a smaller number of intercepts that could cause light scattering (9).

The cement layer applied to the ceramic material is chemically less stable than the ceramic and may undergo color changes over time. Therefore, the samples were stored in dark and relative humidity environment, to avoid degradation of the cement layer, since this was not the objective of this work. However, they were to evaluate the color stability over time. Thus, comparing the effect of aging on the color difference of systems composed by ceramic/cement, it was anticipated that more translucent materials (e.g., feldspathic ceramic) would show higher $\Delta \mathrm{E}_{00}$. In fact, the results of this work confirmed that color changes experienced by the cementing material after aging were much more evident for the feldspathic ceramic. As for the system consisting of a more opaque ceramic material (lithium-disilicate pressed glass ceramic), the color difference after aging was significantly lower compared to that of the porcelain, because much of the light passing through the material was scattered before reaching the cement layer. In this way, the results of the current investigation showed that the color variation due to aging of the resin cement was more noticeable for the bilayer containing the more translucent ceramic.

The results for the color coordinates showed that the feldspathic ceramic groups had an increase in all coordinates after aging, except for the $h^{*}$ coordinate, which decreased after aging. The increase in $a^{*}$ indicates a tendency toward a reddish discoloration and the increase in $b^{*}$ indicates a trend towards a yellowish color (16). These results confirm the fact that the feldspathic ceramic allowed for better visualization of the cement color change. An interesting result for the feldspathic ceramic was the increase of $L^{*}$, showing that despite the cement color change, the sample (ceramic/cement) transmitted a whiter color after aging, becoming brighter. The decrease of $h^{*}$, which represents the hue, indicates that aging caused a less saturated final color. The lithium-disilicate pressed glass ceramic behaved differently regarding the color coordinates, as only values of $a^{*}$ and $h^{*}$ changed significantly. However, calculation of the color difference $\left(\Delta \mathrm{E}_{00}\right)$ showed that these changes were not significant. This shows that lithium-disilicate pressed glass ceramic is more opaque and did not allow perception of cement color change.

The results of this in vitro study are clinically relevant as they showed the importance of understanding how the color of a cemented ceramic restoration may change after aging in the oral environment. A color change in the cement layer is an important factor professional should consider at the time of cementation of a ceramic prosthesis. However, it is important to observe that the perception of color changes due to the cement aging may vary according to the translucency of the ceramic restoration. Therefore, the professional should always be aware of the factors that influence the final result of indirect restorations and be very careful in choosing restorative materials in order to achieve optimal aesthetic results in oral rehabilitation.

In conclusion, the color stability of ceramic/cements bilayers was affected only by the type of ceramic material used for fabrication of the specimens. The more translucent 
material (feldsphatic ceramic) resulted in significantly higher color change after aging in comparison to the less translucent material (Emax lithium disilicate). The resin cement did not affect the color stability of the bilayer after aging.

\section{Resumo}

0 objetivo deste estudo foi avaliar a estabilidade da cor de dois sistemas cerâmicos em função de dois cimentos resinosos, avaliando a diferença de cor $\left(\Delta E_{00}\right)$ pela mensuração de $L^{*}, a^{*}, b^{*}, c^{*}$ e $h^{*}$ de transmitância. Formou-se 4 grupos $(n=5)$ de acordo com as duas cerâmicas (reforçada com dissilicato de lítio e feldspática) e dois cimentos resinosos - cor A3 (RelyX ARC e Variolink II). Dez discos foram confeccionados para cada sistema cerâmico $(10 \times 1,5 \mathrm{~mm})$, tratados com ácido fluorídrico $(10 \%)$ e silanizados antes da cimentação. A análise de cor foi feita 24 $\mathrm{h}$ após a cimentação das amostras e após 6 meses de armazenamento em umidade relativa por meio de espectrofotometria. ANOVA a dois fatores foi utilizada para análise dos dados de $\Delta \mathrm{E}_{00}$ seguido pelo teste de Tukey $(p<0,05)$. ANOVA a um fator foi realizada para avaliação das coordenadas individuais de cor $\left(L^{*}, a^{*}, b^{*}, c^{*} \mathrm{e} \mathrm{h}^{*}\right)$. Apenas o fator cerâmica foi significativo $(p=0,003)$, mas não houve diferença para o fator imento $(p=0,275)$ nem para a interação entre cerâmica e cimento $(p=0,161)$. A cerâmica feldspática apresentou os maiores valores de $\Delta \mathrm{E}_{00}$. Variações de $L^{*}, a^{*}, b^{*}, c^{*}$ e $h^{*}$ foram mais significativas para cerâmica feldspática. Concluiu-se que o armazenamento alterou as propriedades ópticas dos cimentos resinosos de forma semelhante e a porcelana feldspática foi mais susceptivel à mudança de cor do cimento após o envelhecimento.

\section{Acknowledgements}

The authors thank FAPEMIG for the financial support.

\section{References}

1. Peumans $M$, Van Meerbeek $B$, Lambrechts $P$, Vanherle G. Porcelain veneers: a review of the literature. J Dent 2000;28:163-177.

2. Raptis, NV, Michalakis, KX, Hirayama, H. Optical behavior of current ceramic systems. Int J Per Rest Dent 2006;26:31-41.

3. Silami FD, Tonani R, Alandia-Román CC, Pires-de-Souza F de C. Influence of different types of resin luting agents on color stability of ceramic laminate veneers subjected to accelerated artificial aging. Braz Dent J 2016;27:95-100.

4. Niu E, Agustin M, Douglas RD. Color match of machinable lithium disilicate ceramics: Effects of cement color and thickness. J Prosthet Dent 2014;111:42-50.

5. Bagis B, Turgut S. Optical properties of current ceramics systems for laminate veneers. Journal of Dentistry 2013;41 Suppl 3:24-30

6. Conrad HJ, Seong WJ, Pesun IJ. Current ceramic materials and systems with clinical recommendations: a systematic review. J Prosthet Dent 2007;98:389-404.

7. Kelly JR, Benetti P. Ceramic materials in dentistry: historical evolution and current practice. Aust Dent J 2011;56Suppl 1:84-96.

8. McLean JW: Evolution of dental ceramics in the twentieth century. J Prosthet Dent 2001;85:61-66.

9. Heffernan MJ, Aquilino SA, Diaz-Arnold AM, Haselton DR, Stanford
CM, Vargas MA. Relative translucency of six all-ceramic systems. Part II: Core and veneer materials. J Prosthet Dent 2002;88:10-15.

10. Turgut, S, Bagis, B. Color stability of laminate veneers: An in vitro study. Journal of Dentistry 2011;39:57-64.

11. Li $\mathrm{O}, \mathrm{Yu} H$, Wang YN. Spectrophotometric evaluation of the optical influence of core build-up composites on all-ceramic materials. Dental Materials 2009;25:158-165.

12. Pires LA, Novais PM, Araújo VD, Pegoraro LF. Effects of the type and thickness of ceramic, substrate, and cement on the optical color of a lithium disilicate ceramic. J Prosthet Dent 2017;117:144-149.

13. Shono NN, Al Nahedh HN. Contrast ratio and masking ability of three ceramic veneering materials. Oper Dent. 2012;37:406-416.

14. Eder GC, Spoljaric-Lukacic L, Chernev BS. Visualization and characterization of aging induced changes of polymeric surfaces by spectroscopic imaging methods. Anal Bioanal Chem 2012;403:683695.

15. Albuquerque PP, Moreira AD, Moraes RR, Cavalcante LM, Schneider LF. Color stability, conversion, water sorption and solubility of dental composites formulated with different photoinitiator systems. J Dent 2013;41:e67-e72.

16. Almeida JR, Schmitt GU, Kaizer MR, Boscato N, Moraes RR. Resin-based luting agents and color stability of bonded ceramic veneers. J Prosthet Dent 2015;114:272-277.

17. Pereira RD, Valdivia AD, Bicalho AA, Franco SD, Tantbirojn D, Versluis A, et al.. Effect of photoactivation timing on the mechanical properties of resin cements and bond strength of fiberglass post to root dentin. Oper Dent 2015;40:E206-E221.

18. CIE (1976). Colorimetry: official recommendations of the Commission Internationale de I'Éclairage [International Commission on Illumination], CIE No.15 (E-1.3.1)

19. Ghinea R, Pérez MM, Herrera $\amalg$, Rivas MJ, Yebra A, Paravina RD. Color difference thresholds in dental ceramics. J Dent. 2010;38 Suppl 2:e5764.

20. Harianawala HH, Kheur MG, Apte SK, Kale BB, Sethi TS, Kheur $\mathrm{SM}$. Comparative analysis of transmittance for different types of commercially available zirconia and lithium disilicate materials. J Adv Prosthodont 2014;6:456-461.

21. Lopes CCA, Rodrigues RB, Silva AL, Simamoto Júnior PC, Soares CJ, Novais VR. Degree of conversion and mechanical properties of resin cements cured through different all-ceramic systems. Braz Dent J 2015;26:484-489.

22. Koishi Y, Tanoue N, Atsuta M, Matsumura H. Influence of visible-light exposure on colour stability of current dual curable luting composites. Journal of Oral Rehabilitation 2002;29:387-393.

23. Chen XD, Hong G, Xing WZ, Wang YN. The influence of resin cements on the final color of ceramic veneers. J Prosthodont Res 2015;59:172-177.

24. Zahng $Y$, Griggs JA, Benham BS. Influence of powder/liquid mixing ratio on porosity and translucency of dental porcelains. J Prosthet Dent 2004;91:128-135.

25. Yoshimura HN, Goldenstein, $\mathrm{H}$. Light scattering in polycrystalline alumina with bi-dimensionally large surface grains. J Eur Ceram Soc 2009;25:293-303. 